\title{
INFLUENCE OF IMPROVERS ON BIOCHEMICAL PROCESSES IN THE DOUGH WITH WHEAT BRAN AND DRY WHEY
}

\author{
O. Bortnichuk, V. Dotsenko, V. Tsirulnikova \\ National University of Food Technologies
}

\begin{tabular}{|c|c|}
\hline Key words: & ABSTRACT \\
\hline $\begin{array}{l}\text { Lecithin } \\
\text { Dry whey } \\
\text { Wheat bran } \\
\text { Hydrolysis } \\
\text { Bakery products }\end{array}$ & $\begin{array}{l}\text { The article describes the effect of lecithin and enzymatic } \\
\text { modification of lactose on biochemical processes in dough } \\
\text { with wheat bran and dry whey. Changes in qualitative and } \\
\text { quantitative characteristics of baker's yeast were shown. Re- } \\
\text { gularities of sugar formation in the dough at the beginning }\end{array}$ \\
\hline $\begin{array}{l}\quad \text { Article history: } \\
\text { Received } 13.11 .2017 \\
\text { Received in revised form } \\
04.12 .2017 \\
\text { Accepted } 26.12 .2017\end{array}$ & $\begin{array}{l}\text { and after } 180 \text { minutes of fermentation with the use of } \\
\text { selected raw materials and improvers were established. The } \\
\text { influence of dry milk whey, wheat bran, lecithin and enzy- } \\
\text { matic modification of lactose on the parameters of active } \\
\text { and titrated acidity in the dough was studied. The efficiency }\end{array}$ \\
\hline $\begin{array}{l}\text { Corresponding author: } \\
\text { O. Bortnichuk } \\
\text { E-mail: } \\
\text { npnuht@ukr.net }\end{array}$ & $\begin{array}{l}\text { of using lecithin and } \beta \text {-galactosidase enzyme for bakery } \\
\text { products with the use of milk whey and wheat bran was } \\
\text { proved. }\end{array}$ \\
\hline
\end{tabular}

DOI: $10.24263 / 2225-2924-2017-23-6-18$

\section{ВПЛИВ ПОЛІПШУВАЧІВ НА БІОХІМІЧНІ ПРОЦЕСИ \\ В TICTI 3 ПШЕНИЧНИМИ ВИСІВКАМИ I СУХОю МОЛОЧНОЮ СИРОВАТКОЮ}

\author{
О.В. Бортнічук, В.Ф. Доценко, В.В. Цирульнікова \\ Національний університет харчових технологій
}

У статті описано вплив лецитину та ферментативної модифікації лактози на біохімічні прочеси в тісті з пшеничними висівками й сухою молочною сироваткою. Показано зміни в якісних і кількісних характеристиках хлібопекарських дріжджів, встановлено закономірності иукроутворення в тісті на початку та за 180 хв його бродіння при сумісному використанні обраної сировини й поліпшувачів. Досліджено вплив сухої молочної сироватки, пшеничних висівок, лецитину та ферментативної модифікаиї лактози на показники активної й титрованої кислотності в тісті. Доведено ефективність використання лецитину та ферменту $\beta$-галактозидази для приготування хлібобулочних виробів із використанням молочної сироватки й пшеничних висівок.

Ключові слова: лечитин, суха молочна сироватка, пшеничні висівки, гідроліз, хлібобулочні вироби. 
Постановка проблеми. Хлібобулочні вироби, зазвичай, виготовляються із борошна вищих сортів, тому вони мають досить високу енергетичну цінність, адже борошно на 70\% складається з вуглеводів, які легко засвоюються. Білкові речовини хліба складають лише $6,5 \ldots 11 \%$. Вони представлені, власне, білками, а також продуктами їх гідролізу — пептидами, поліпептидами, амідами та амінокислотами, серед яких наявні всі вісім незамінних. Проте кількість триптофану, лізину та метіоніну досить низька і є визначальною в оцінці біологічної цінності хліба [5].

Також важлива функціональна дія продуктів на основі борошна залежить від вмісту в ньому розчинних і нерозчинних харчових волокон, які сприяють зниженню ризику серцево-судинних захворювань, зменшують рівень холестерину та стабілізують травні функції організму, запобігаючи захворюванням шлунково-кишкового тракту [1].

Функціональні властивості хлібобулочних виробів можуть бути підвищені за рахунок додаткового внесення в їх рецептуру сировини, багатої на харчові волокна та білок 3 високим вмістом амінокислот триптофану, лізину, метіоніну, що $є$ лімітуючими в даних продуктах $[6 ; 8 ; 9]$.

Провідними науковцями було показано позитивну тенденцію при окремому використанні в технології хлібобулочних виробів вторинних продуктів переробки харчової промисловості, таких як суха молочна сироватка (СМС) та пшеничні висівки (ПВ). Проте у вітчизняній і зарубіжній літературі не зустрічається даних про перспективи сумісного використання ПВ та СМС у рецептурі виробів із пшеничного борошна 3 метою покращення їх функціональних властивостей.

Нами в попередніх дослідженнях визначено оптимальне дозування сухої молочної сироватки та пшеничних висівок - відповідно 5\% та 10\% до маси борошна. Доведено позитивний вплив лецитину та ферментативної модифікації лактози на якість готових виробів з обраною сировиною [2-4].

Метою дослідження $\epsilon$ встановлення закономірностей і сутності біохімічних і мікробіологічних процесів, що відбуваються в тісті з обраною сировиною та поліпшувачами.

Матеріали і методи. Газоутворення досліджували волюмометричним методом на приладі АГ-1М. Активність молочнокислих бактерій, мальтазну та зимазну активності, бродильну активність, осмочутливість і підйомну силу дріжджів, динаміку активної й титрованої кислотності визначали за методиками, наведеними в лабораторному практикумі [7]. Вміст цукрів проводили йодометричним методом. Визначення накопичення дріжджів у тісті протягом 4 год його дозрівання проводили підрахунком мікроорганізмів у камері Горяєва. Тісто готували традиційним безопарним способом, що включає підготовку та дозування сировини, замішування дріжджового тіста, його бродіння, розподіл, формування, вистоювання тістових заготовок та їх випікання. Замішування тіста здійснювали в лабораторній тістомісильній машині протягом $9 . \ldots 11$ хв. Тривалість бродіння тіста становила 160 хв при температурі $30 \pm 2^{\circ} \mathrm{C}$. Вироби формували вручну, вистоювали тістові заготовки до готовності при температурі $30 \ldots 32^{\circ} \mathrm{C}$ і відносній вологості $75 \ldots 80 \%$. Випікали хліб формовий у пекарській шафі UNOX при $t=200 \ldots 220^{\circ} \mathrm{C}$. 
Контрольним був зразок, до складу якого входило пшеничне борошно першого сорту без добавок - контроль-1, та зразок із пшеничними висівками у кількості $10 \%$ та сухою молочною сироваткою 5\% до маси борошна контроль-2.

Викладення основних результатів дослідження. Основний показник, що характеризує інтенсивность спиртового бродіння - кількість виділеного діоксиду вуглецю під час бродіння тіста. Внесення в тісто досліджуваної сировини впливає на рівень його газоутворювальної здатності, яка відображає активність дріжджових клітин і забезпеченість їх живленням.

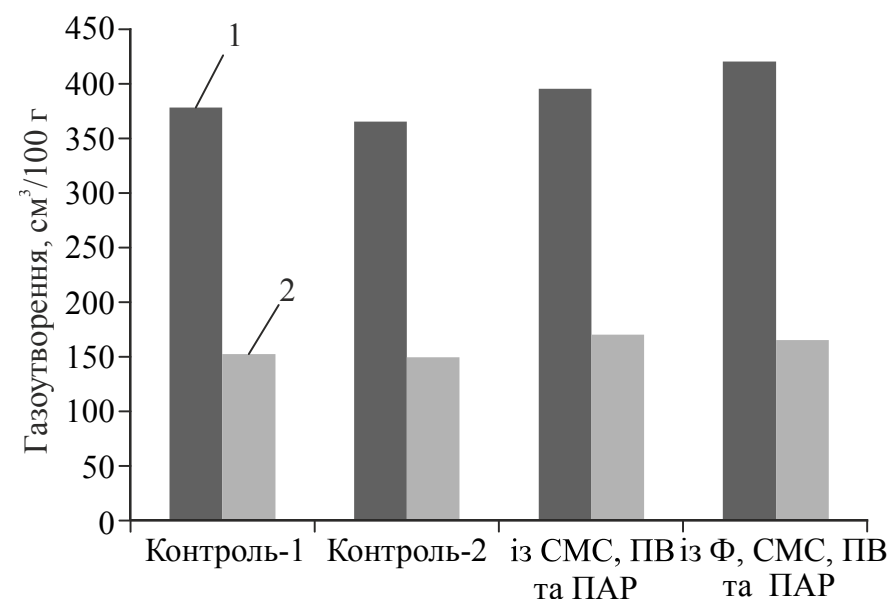

Рис. 1. Вплив досліджуваної сировини та поліпшувачів

на інтенсивність газоутворення в тісті при: 1 - бродінні; 2 - вистоюванні

Встановлено (рис. 1), що сумісне внесення пшеничних висівок і сухої молочної сироватки спричиняє зниження інтенсивності виділення вуглекислого газу дріжджовою мікрофлорою на 3,0\%. Водночас внесення до досліджуваної сировини поверхнево-активної речовини може сприяти підвищенню газоутворення в тісті. Показник виділення діоксиду вуглецю при використанні емульгатора лецитину перевищує показники газоутворення контрольного зразка без добавок на $6,6 \%$, зразка з ПВ і СМC - на 9,9\%.

Очевидно, це пов'язано з дією фосфоліпідної складової ПАР, яка сприяє більш ефективному доступу продуктів живлення до дріжджової клітини. Це $є$ важливим фактором на етапі приготування тіста.

Встановлено, що при застосуванні ферментативної модифікації лактози в тісті також спостерігається підвищення газоутворення. Така тенденція, очевидно, спричинена накопиченням простих цукрів, що утворюються в процесі гідролізу лактози, які використовуються як ефективне джерело живлення бродильною мікрофлорою.

3 отриманих результатів можна зробити висновок, що використання поверхнево-активної речовини та $\beta$-галактозидази сумісно з харчовими волокнами й молочним продуктом дає змогу інтенсифікувати спиртове бродіння в тісті порівняно з контрольним зразком без добавок на 10,4\%. 
Для визначення впливу поліпшувачів на біотехнологічниі властивостей дріжджової мікрофлори досліджено швидкість утворення діоксиду вуглецю в тісті (рис. 2).

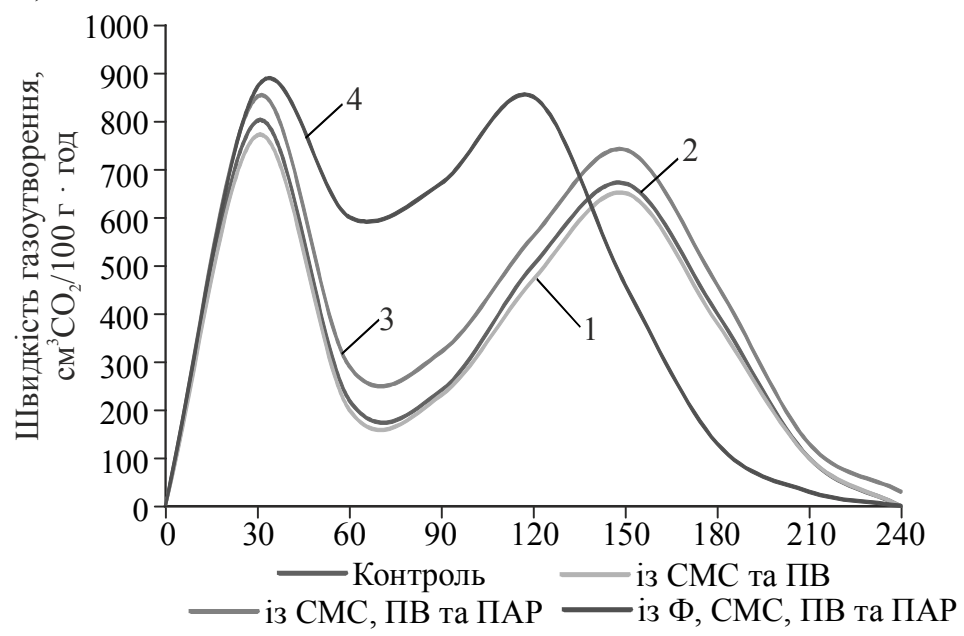

Рис. 2. Кінетика утворення діоксиду вуглецю в зразках тіста:

1 - контроль-1 (без добавок); 2 — контроль-2 (із СМС та ПВ); 3 - із СМС, ПВ та ПАР; 4 - із СМС, ПВ, ПАР та $\Phi$

Як видно з рис. 2, спостерігається стійка тенденція більш інтенсивного виділення діоксиду вуглецю у зразках тіста з використанням ПАР порівняно 3 контрольними зразками. Отримані дані дають змогу стверджувати, що внесення лецитину до рецептури покращує кінетику накопичення діоксиду вуглецю.

Внесення $\beta$-галактозидази безпосередньо в тісто також сприяє прискоренню утворення вуглекислого газу в тісті. При цьому другий пік швидкості газоутворення припадає на $110 \ldots 120$ хв бродіння, що дає змогу спрогнозувати скорочення технологічного процесу виробництва на $30 \ldots 40$ хв.

Для чіткого розуміння зміни динаміки виділення діоксиду вуглецю в тісті було досліджено вплив кожного із компонентів на життедіяльність дріжджів.

Бродильну активність дріжджів визначали за підйомною силою, зимазною і мальтазною активністю.

3 рис. 3 видно, що сумісне внесення ПВ і СМС у тісто негативно впливає на підйомну силу дріжджової мікрофлори. Бродильна активність дріжджів зменшується на $14,3 \%$.

Проте використання емульгатора у вказаній кількості дає змогу покращити цей показник, наблизити його до контрольного зразка. Ферментативна модифікація лактози разом з ПАР справляе позитивний вплив на підйомну силу дріжджів - вона покращується на 9,6\% порівняно із контролем без добавок.

Очевидно при додаванні молочної сироватки та пшеничних висівок відбувається зміна осмотичного тиску в системі, що негативно впливає на інтенсивність ферментних систем мікроорганізмів.

Здатність дріжджів зберігати ферментативну активність за наявності речовин, що підвищують осмотичний тиск, характеризується показником їх осмочутливості. 
У наших дослідах осмочутливість визначали за підйомною силою дріжджів у тісті без солі і зі збільшеним вмістом солі як сировини, що створює підвищений осмотичний тиск.

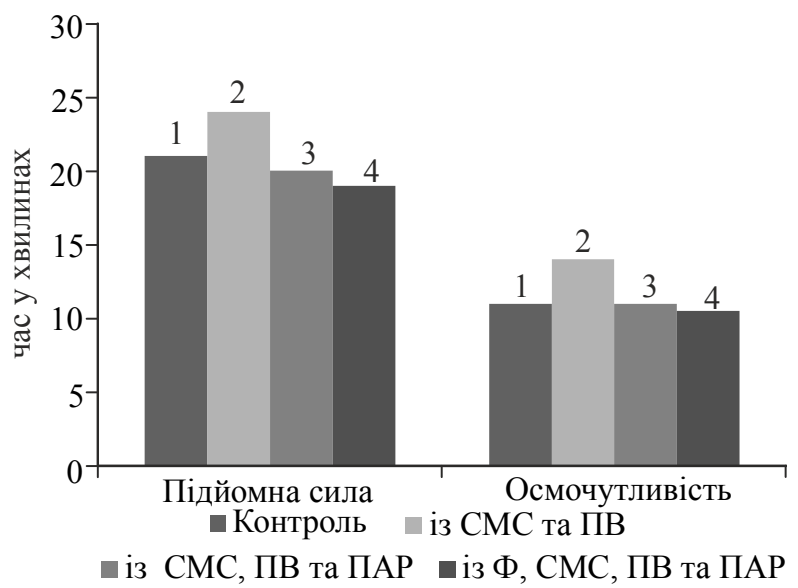

Рис. 3. Вплив досліджуваної сировини і поліпшувачів на підйомну силу та осмочутливість дріжджів: 1 - контроль-1 (без добавок); 2 -контроль-2 (із СМС та ПВ); 3 - із СМС, ПВ та ПАР; 4 - із СМС, ПВ, ПАР та Ф

Як видно з даних (рис. 3), осмочутливість дріжджів при внесенні СМС та ПВ зменшується на 27,3\% порівняно з контролем. Внесення емульгатора, як i при дослідженні підйомної сили дріжджів, дає змогу урівноважити розподіл енергії у системі та наблизити показник осмочутливості дріжджової клітини до показників контролю без добавок.

Для об'єктивної оцінки технологічних аспектів і встановлення особливостей впливу компонентів композиції на дріжджову мікрофлору також проводили визначення накопичення дріжджових клітин у процесі бродіння, зимазну та мальтазну активності дріжджів для досліджуваних зразків.

Для визначення кількості накопичення дріжджової мікрофлори готували безопарне тісто вологістю 44\%. Пресовані дріжджі вносили в кількості $3 \%$ до маси борошна.

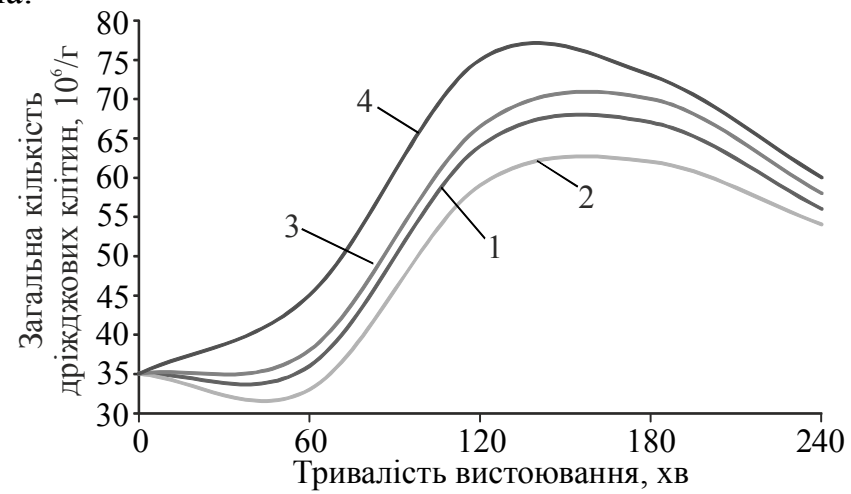

Рис. 4. Накопичення дріжджових клітин у тісті в процесі 4 год бродіння:

1 - контроль-1 (без добавок); 2 - контроль-2 (із СМС та ПВ); 3 - із СМС, ПВ та ПАР; 4 - із СМС, ПВ, ПАР та $\Phi$ 
Результати дослідження свідчать про те (рис. 4), що сумісне внесення ПВ і СМС (котроль-2) гальмує приріст дріжджової мікрофлори. На всіх етапах відбору проб показник приросту був менший, ніж для контролю без добавок. Використання лецитину позитивно впливає на динаміку накопичення бродильної мікрофлори і вона знаходиться на рівні дещо вищому, ніж контроль, що корелює з результатами попередніх досліджень.

Встановлено, що проведення гідролізу лактози СМС при бродінні тіста інтенсифікує накопичення дріжджових клітин в ньому. Слід відмітити, що згідно 3 даними, наведеними на рис. 4, максимальна кількість накопичення КУО бродильної мікрофлори для зразка з $\beta$-галактозидазою, СМС, ПВ та ПАР спостерігається на $120 \ldots 130$ хв бродіння, а для зразка без використання ферменту найбільша кількість КУО дріжджі спостерігається дещо пізніше — на 150...160 хв.

Таким чином, результати, отримані при дослідженні динаміки накопичення дріжджової мікрофлори, корелюють 3 результатами попередніх досліджень, підтверджують ефективність застосування лецитину як поліпшувача та можливість скорочення технологічного процесу при застосуванні гідролізу молочного цукру в тісті з СМС.

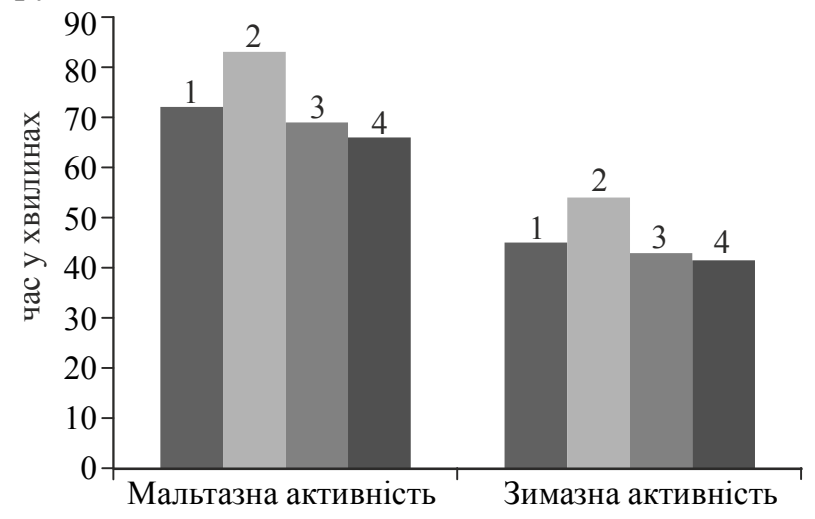

Рис. 5. Вплив досліджуваної сировини на мальтазну та зимазну активності дріжджів: 1 - контроль-1 (без добавок); 2 - контроль-2 (із СМС та ПВ); 3 - із СМС, ПВ та ПАР; 4 - iз СМС, ПВ, ПАР та $\Phi$

Зазвичай, на показники газоутворення, підйомної сили та накопичення дріжджових клітин впливає здатність дріжджів ефективно асимілювати продукти живлення. Тому було реалізовано модельний дослід, в якому до розчину цукрів (мальтози та глюкози) додавали СМС і ПВ, СМС, ПВ і ПАР, а також СМС ПВ, ПАР та $\beta$-галактозидазу у кількостях, що забезпечують реальне співвідношення дріжджів і цих компонентів у рецептурі виробу.

Традиційно вважається, що хороші дріжджі повинні мати зимазну активність до 70 хв, а мальтазну — до 110 хв.

У дослідженнях найкращу зимазну активність $43 \ldots 45$ хв мали дріжджі у зразку з гідролізом лактози, СМС, ПВ і лецитином, найгірший результат активності зимазного комплексу $54 . .56$ хв був зафіксований для мікрофлори зразку з молочним продуктом і пшеничними висівками. Зразок з ПАР, СМС та ПВ показав результати, наближені до контролю. Із отриманих даних можна зробити висновок про те, що використання поліпшувача буде сприяти 
інтенсифікації життєдіяльності дріжджів одразу після замісу тіста, а застосування гідролізу лактози тільки підсилює даний ефект.

Індуктивний період утворення мальтази у різних дріжджів різний i за даними І.К. Єлецького складає приблизно 90-120 хв [8]. Мальтазна активність має особливо важливе значення для опарного і безопарного способів приготування тіста, загальна тривалість дозрівання яких складає 220-360 хв.

Із рис. 5 видно, що сумісне внесення в тісто сухої молочної сироватки та пшеничних висівок (контроль-2) призводить до погіршення мальтазної активність дріжджів. Порівняно 3 контролем активність ферментного комплексу знижується на 15,3\%. Проте залучення поліпшувача, як і при визначенні зимазної активності, дає змогу покращити інтенсивність зброджування мальтози і глюкози до показників контрольного зразка.

Даний факт, очевидно, пояснюється покращенням доступності цукрів до дріжджової клітини за рахунок дії ПАР на оболонку та цитоплазматичну мембрану дріжджової клітини і накопиченням простих цукрів при застосуванні гідролізу лактози. Таким чином, спостерігається інтенсивніше виділення діоксиду вуглецю в тісті з сухою молочною сироваткою, пшеничними висівками і ПАР.

Для більш чіткої картини впливу обраної сировини та поліпшувачів на мікрофлору тіста було досліджено активність молочнокислих бактерій у зразках (табл. 1).

\section{Таблиия 1. Вплив сировини і поліпшувачів на активність молочнокислих бактерій}

\begin{tabular}{|c|c|c|c|c|}
\hline \multirow{2}{*}{ Показник } & \multicolumn{4}{|c|}{ Значення показника в зразках } \\
\cline { 2 - 5 } & $\begin{array}{c}\text { Контроль-1 } \\
\text { (без добавок) }\end{array}$ & $\begin{array}{c}\text { Контроль-2 } \\
\text { (із СМС та ПВ) }\end{array}$ & $\begin{array}{c}\text { із СМС, ПВ } \\
\text { та ПАР }\end{array}$ & $\begin{array}{c}\text { із Ф, СМС, } \\
\text { ПВ та ПАР }\end{array}$ \\
\hline $\begin{array}{c}\text { Тривалість знебарвлення } \\
\text { метиленової сині, хв }\end{array}$ & $205 \pm 2$ & $217 \pm 2$ & $206 \pm 2$ & $198 \pm 2$ \\
\hline
\end{tabular}

Життєдіяльність молочнокислих бактерій має аналогічну закономірність зі зміною активності сахароміцетів. Як видно з табл. 1, тривалість знебарвлення метиленової сині для зразка із сухою молочною сироваткою та пшеничними висівками (контроль-2) є вищою, ніж для зразка із лецитином і ферментом на 9,6\%, що свідчить про підвищення активності молочнокислих бактерій при додаванні поліпшувачів.

Отже, за результатами досліджень можна констатувати, що за наявності лецитину інтенсифікується асиміляція поживних речовин молочнокислими бактеріями на 5,3\%, проведення гідролізу лактози СМС в тісті додатково сприяє активізації молочнокислих бактерій за рахунок утворення простих цукрів, які легко засвоюються мікроорганізмами, внаслідок чого відбувається більш інтенсивне виділення продуктів життєдіяльності - органічних кислот, вуглекислого газу, які забезпечують спрямованість і повноту колоїдних, фізичних та біохімічних процесів у тістових напівфабрикатах, що в сукупності і характеризує ступінь їх готовності.

Інтенсивність бродіння залежить передусім від активності дріжджової клітини, наявності живлення для неї, а також від параметрів технологічного процесу: температури, вологості та рН тіста. 
Кислотність має вирішальне технологічне значення, оскільки за певної кислотності напівфабрикатів відбуваються процеси пептизації і набухання білкових речовин, активізуються ферменти борошна, дріжджів, накопичуються кислотореагуючі сполуки, що формують необхідні реологічні, органолептичні властивості і фізико-хімічні показники якості готових виробів. Тому метою подальших досліджень було визначення динаміки титрованої й активної кислотностей тіста для зразків з поліпшувачем і без нього.

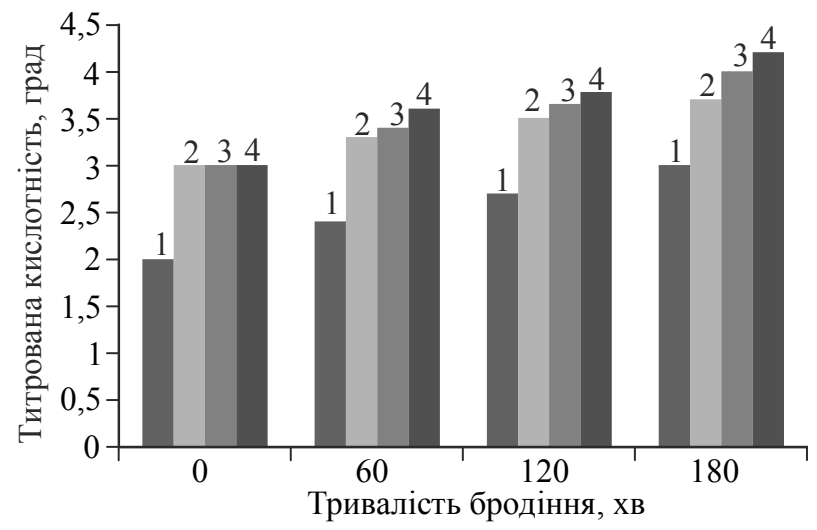

Рис. 6. Динаміка титрованої кислотності тіста в процесі бродіння:

1 - контроль-1 (без добавок); 2 — контроль-2 (із СМС та ПВ); 3 - із СМС, ПВ та ПАР; 4 - iз СМС, ПВ, ПАР та $\Phi$

Отримані результати (рис. 6) свідчать, що внесення в тісто пшеничних висівок і сухої молочної сироватки призводить до підвищення початкової кислотності тіста на 0,4 град, що пояснюється власною кислотністю молочного продукту. Додавання лецитину та ферменту до рецептури не впливає на титровану кислотність. Під час бродіння кислотність тіста для всіх зразків підвищується.

Слід відмітити, що при бродінні рівень активної кислотності залишається в оптимальних межах для бродильної мікрофлори. При тривалості бродіння $170 \ldots 180$ хв ферментативна модифікація лактози може уповільнюватись, адже значення рН дещо нижче п’яти (рис. 7), що є незначним відхиленням від оптимального $\mathrm{pH}$ для дії $\beta$-галактозидази.

Дослідження динаміки активної кислотності тіста показали, що внесення ПАР і ферментативна модифікація лактози позитивно впливають на підвищення рівня титрованої кислотності в процесі його бродіння на 1,2 град. Така тенденція очевидно зумовлена здатністю поліпшувача та ферментного препарату позитивно впливати на розвиток мікрофлори в тісті (рис. $1-5$, табл. 1 ), сприяти інтенсивнішому споживанню поживних речовин 3 утворенням продуктів їх розпаду.

Для пояснення впливу ПАР на вуглеводно-амілазний комплекс і дослідження ефективності процесу ферментативного гідролізу молочної сироватки вивчали динаміку цукроутворювальної здатності в тісті 3 досліджуваною сировиною. 
Як зразки для дослідження обрано тісто, до рецептури якого не внесено дріжджі хлібопекарські пресовані з метою запобігання впливу їх ферментів на процес амілолізу, а також тісто з додаванням 3\% дріжджів. Умови експерименту такі: температура $(30 \pm 2)^{\circ} \mathrm{C}$, тривалість вистоювання 3 год. Накопичення цукрів визначали за різницею між вмістом одразу після замісу і після відведеного часу для ферментативних перетворень за йодометричним методом Шорля. Для визначення балансу цукрів готували чотири зразки тіста контроль-1 (без добавок) і з внесенням досліджуваних компонентів до маси борошна контроль-2 (із сумісним внесенням 5\% СМС та 10\% ПВ); $3-5 \%$ СМС, $10 \%$ ПВ та 0,7\% ПАР; 4-5\% СМС, $10 \%$ ПВ, 0,7\% ПАР та внесення в тісто ферменту $\beta$-галактозидази.

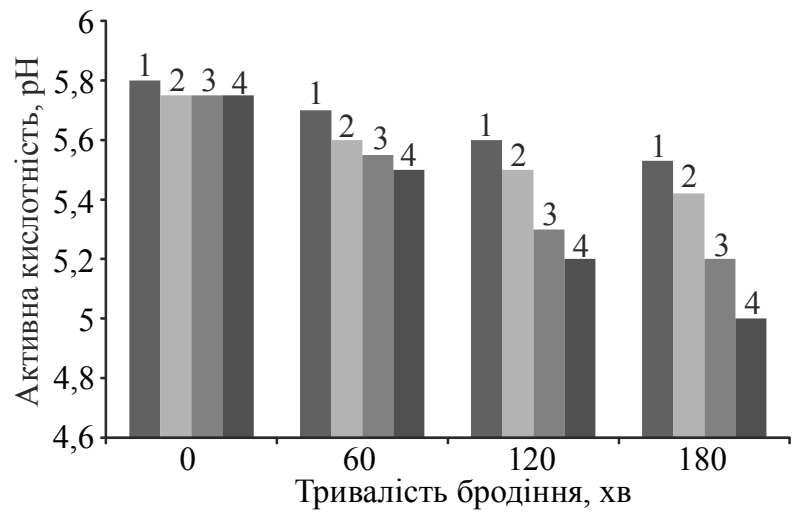

Рис. 7. Динаміка активної кислотності зразків тіста в процесі бродіння:

1 - контроль-1 (без добавок); 2 — контроль-2 (із СМС та ПВ); 3 - із СМС, ПВ та ПАР; 4 - із СМС, ПВ, ПАР та Ф

3 табл. 2 видно, що в тісті 3 додаванням досліджуваних сировини (як за наявності дріжджів, так і без них) вміст цукрів одразу після замісу вищий, ніж у контролі без добавок, на 43,6...45,5\% відповідно. Дана тенденція зумовлена внесенням у тісто додаткової кількості редукуючих цукрів разом із молочною сироваткою.

Таблиця 2. Динаміка цукроутворення в тісті 3 досліджуваною сировиною $\mathbf{i}$ поліпшувачами (масова частка мальтози, \% на СР)

\begin{tabular}{|c|c|c|c|c|}
\hline \multirow{2}{*}{$\begin{array}{c}\text { Час відбору проб, } \\
\text { год }\end{array}$} & $\begin{array}{c}\text { Контроль-1 } \\
\text { (без добавок) }\end{array}$ & $\begin{array}{c}\text { Контроль-2 } \\
\text { (із СМС та ПВ) }\end{array}$ & $\begin{array}{c}\text { Тісто з борошна пшеничного } \\
\text { 1-го сорту 3 додаванням }\end{array}$ \\
\cline { 3 - 5 } & $\begin{array}{c}\text { СМ, ПВ та } \\
\text { ПАР }\end{array}$ & $\begin{array}{c}\text { Ф, СМС,ПВ та } \\
\text { ПАР }\end{array}$ \\
\hline \multicolumn{5}{|c|}{ Бездріжджове тісто } \\
\hline 0 & $2,02 \pm 0,02$ & $2,92 \pm 0,03$ & $2,9 \pm 0,03$ & $2,94 \pm 0,03$ \\
\hline 3 & $3,64 \pm 0,03$ & $4,75 \pm 0,05$ & $4,71 \pm 0,05$ & $6,79 \pm 0,07$ \\
\hline Накопичено & $1,62 \pm 0,02$ & $1,83 \pm 0,02$ & $1,81 \pm 0,02$ & $3,85 \pm 0,04$ \\
\hline \multicolumn{5}{|c|}{ Дріжджове тісто } \\
\hline 0 & $2,02 \pm 0,02$ & $2,92 \pm 0,03$ & $2,9 \pm 0,03$ & $2,94 \pm 0,03$ \\
\hline 3 & $1,37 \pm 0,01$ & $2,72 \pm 0,03$ & $1,97 \pm 0,02$ & $3,81 \pm 0,04$ \\
\hline Накопичено & - & - & - & $0,67 \pm 0,01$ \\
\hline Зброджено & $2,27 \pm 0,02$ & $2,03 \pm 0,02$ & $2,76 \pm 0,03$ & $3,08 \pm 0,03$ \\
\hline
\end{tabular}


Встановлено, що масова часка накопичених цукрів 3 молочною сироваткою та пшеничними висівками є вищою порівняно із контролем на $13 \%$. Це пояснюється початково вищим вмістом вуглеводів у зразках із досліджуваною сировиною.

Слід відмітити, що внесення ПАР до системи дещо гальмує процес накопичення редукуючих цукрів у бездріжджовій системі.

Очевидно, зниження інтенсивності розщеплення крохмалю ферментами борошна за наявності ПАР можна пояснити меншою доступністю крохмалевого субстрату до дії ферментів за рахунок утворення комплексів емульгатор-крохмаль.

Дослідження показали, що гідроліз лактози забезпечує збільшення накопичення цукрів порівняно із системою без ферменту на $113 \%$. Таким чином, підтверджується ефективність використання $\beta$-галактозидази для гідролізу молочного цукру в тісті.

Незважаючи на більше накопичення цукрів для зразка контроль-2, інтенсивність збродження знижується, що корелює з підйомною силою дріжджів у кількістю виділеного вуглекислого газу.

Надалі буде досліджено вплив обраної сировини та поліпшувачів на структурно-механічні властивості тіста, фракційний склад білка, а також визначено споживчі та фізіологічні показники готових хлібобулочних виробів.

\section{Висновки}

Проведеними дослідженнями встановлено зміни в перебігу основних біохімічних і мікробіологічних процесів при додаванні обраної сировини та поліпшувачів:

1. При сумісному внесенні СМС і ПВ у тісто в ньому знижується газоутворення на $3,0 \%$ порівняно зі зразком без добавок. Використання лецитину та ферментативна модифікація лактози при бродінні тіста дає змогу підвищити газоутворення рівень газоутворення.

2. Встановлено, що лецитин позитивно впливає на життєдіяльність дріжджових клітин у середовищі з СМС і ПВ. Покращуються їх підйомна сила та осмочутливість - на $16,7 \%$ та $21,4 \%$ відповідно. Застосування ПАР покращує динаміку накопичення дріжджових клітин. Одночасне використання гідролізу лактози й емульгатора дає змогу інтенсифікувати накопичення бродильної мікрофлори на 7,1\% в точках екстремуму, покращити мальтазну та зимазну активності на $4,3 \%$ та $3,5 \%$ відповідно.

3. Визначено, що додавання лецитину та проведення ферментативної модифікації лактози не впливають на початкову активну й титровану кислотності тіста.

4. Встановлено, що із додаванням досліджуваної сировини вміст цукрів одразу після замісу вищий, ніж у контролі, на $43,6 \ldots 45,5 \%$. Ферментативна модифікація лактози призводить до збільшення накопичення цукрів порівняно із системою без ферменту на $113 \%$. Використання лецитину приводить до підвищення масової частки зброджених цукрів у тісті на 20,5\%.

\section{Література}

1. Rimbach G., Boesch-Saadatmandi C., Frank J., Fuchs D., Wenzel U., Daniel H., Hall WL,. Weinberg $P D$. Dietary isoflavones in the prevention of cardiovascular disease. - A molecular perspective Food Chem Toxicol. 2008;46:1308-1319. 
2. Бортнічук O.B. Інноваційні підходи в технології хлібобулочних виробів з сухою молочною сироваткою / О.В. Бортнічук, А.В. Гавриш, О.В. Нєміріч, В.Ф. Доценко // Харчова наука і технологія. — 2015. — № 2(31). — С. 97-102.

3. Бортнічук O.B. Вплив гідролізу лактози сухої молочної сироватки на інтенсивність бродіння тіста / О.В. Бортнічук, Н.О. Лець, А.В. Гавриш, О.В. Нєміріч, В.Ф. Доценко // Хлібопекарська і кондитерська промисловість України. - 2015. - 06(127). - С. 3 -6.

4. Бортнічук $O . B$. Використання пшеничних висівок у виробництві хлібобулочних виробів / О.В. Бортнічук, В.В. Цирульнікова, В.Ф. Доценко // Sword. — 2014. — № 3(36). C. $15-21$.

5. Грек О.В. Перспективы использования белков молочной сыворотки / О.В. Грек, А.В. Тимчук // Україна - Польша - СС: економіко-правові аспекти розвитку освіти $\mathrm{i}$ бізнесу : Зб. матеріалів міжнародного науково-практичного форуму. — Херсон : ПП Вишемирский В.С., 2013. - С. 42-47.

6. Елецкий И.К. Биотехнологические свойства полуфабрикатов при производстве хлебопекарных изделий. - Москва : МГУПП. 2007. - С. 21-31

7. Лабораторний практикум з технології хлібопекарного та макаронного виробництва : навч. посібник / В.І. Дробот, Л.Ю. Арсеньєва, О.А. Білик та ін. - К.: Центр навчальної літератури, 2006. - $341 \mathrm{c.}$

8. Мусина О.Н. Поликомпонентные продукты на основе комбинированного сырья / О.Н. Мусина, М.П. Щетинин. — Барнаул : АлтГУ. 2010. — 243 с.

9. Храмиов А.Г. Феномен молочной сыворотки [Текст] / А.Г. Храмцов. - СанктПетербург : Профессия, 2011. — 802 с. 